\title{
SOCIAL INTERACTION AND ACADEMIC PERFORMANCE OF DEAF AND HARD OF HEARING STUDENTS IN CEBU CITY, PHILIPPINES
}

\author{
Janine Joy L. Tenerife ${ }^{1 \mathrm{i}}$, \\ Emerson D. Peteros', \\ Susana D. Manreal ${ }^{3}$, \\ Lilibeth C. Pinili' ${ }^{4}$, \\ John V. de Vera ${ }^{5}$, \\ Jesilyn D. Peconcillo', \\ Lindley S. Saladaga ${ }^{7}$ \\ 1,2,4,7College of Education, \\ Cebu Technological University-Main Campus, \\ Cebu City, Cebu, \\ Philippines \\ ${ }^{3}$ Special Education, \\ First High School for the Hearing Impaired, \\ Cebu City, Cebu, \\ Philippines \\ ${ }^{5}$ College of Education, \\ Cebu Technological University-Naga Extension Campus, \\ City of Naga, Cebu, \\ Philippines \\ ${ }_{6}^{6}$ Preschool Vicenta A. Manreal Elementary School, \\ Talisay City, Cebu, \\ Philippines
}

\begin{abstract}
:
This research assessed the social interaction and the academic performance of the deaf and hard of hearing students in a school for the deaf in Cebu City, Philippines. There were 49 respondents who were assessed in terms of their social interaction and academic performance. A survey questionnaire was used to assess the level of their social interaction and their grades were used to measure their academic performance. Data gathered were treated statistically using descriptive and inferential statistics. Results showed that the respondents had an average age of 19.5 years old that are deaf with 3 to 4 siblings. The respondents had high social interaction with their teachers and peers but had moderate social interaction with their family members and very low social interaction with the hearing students. They perform satisfactorily in school. There were significant relationships between their interaction with their family members and the hearing students. Thus, school administrators are encouraged to design programs that
\end{abstract}

${ }^{i}$ Correspondence: email peterosemerson@gmail.com 
would improve the social interactions of the deaf and hard of hearing students within the school community and at home.

Keywords: social interaction, academic performance, deaf, hard of hearing students

\section{Introduction}

Over the years, it has always been an issue that the society disregarded persons with disabilities and minority groups present in the community in which the deaf people are not an exception. At present, although there has been a significant improvement on the role of the deaf people in the society, there are still barriers between the communication of the deaf and the hearing people (Hankins, 2015). Even in the United States which is considered advanced when it comes to the protection of the rights of the people and in providing assistance to the less fortunate citizens of the country, deaf people had been victims of misjudgments of the hearing people. Because of their lack of spoken communication, they were stereotyped to have mental disorder, low intelligence and being taught unjustly with the hearing people in schools (Hankins, 2015).

Deaf people are misjudged and misunderstood because their disabilities are not seen by their physical appearance. Thus, they suffer these consequences from the hearing people who are not aware of their situation. The social interaction of the deaf people is affected because of these communication barriers between the hearing world and the deaf (LaBelle, Booth-Butterfield, \& Rittenour, 2013). There had been fewer efforts from the hearing world to reach out to the deaf people so that social interaction between these two sectors will be made possible. It is only through sign language in which the hearing world and the deaf can communicate effectively. However, only few of the hearing people learn sign language. Though the hearing people can communicate with the deaf using modified sign language, this method is not always effective in order to engage to the deaf. With the existing communication barriers between the deaf and hearing people, the deaf community oftentimes engage socially only among themselves where they can feel that they are welcomed by their peers. Social interactions among these people are more evident than their interaction with the hearing world. Even in the family, the deaf people are most of the time given less attention by their family members. Parents also struggle in communicating with their children with hearing difficulties especially if parents are not well-versed in communicating with the deaf. This is often the cause of conflict between the child and the parents because both sides cannot express their feelings and emotions effectively in order to relay the information intended for each other (Correll, 2017).

Similarly, when the deaf children are in school, they suffer the same situation with the hearing people. But it is in school where they can find belongingness when the school caters deaf students. They can establish social relationship among their peers because it would be easy for them to communicate in their own world including teachers who are 
handling these students (Wanjiru, 2014). Teachers could serve as second parents to these students in school which reinforce the role of parents at home. Since most of the time teachers can communicate effectively to the deaf students than their parents, deaf students express their feelings more effectively to the teachers including their problems at home. There are times that teachers serve as counselors to these deaf students with regards to their problems at home and even their personal life.

In the school where the researchers conducted the study, it caters deaf and hard of hearing students $(\mathrm{D} / \mathrm{HH})$ exclusively. This school is inside the vicinity of a national high school which caters regular students. It is a common complain of parents in this school that their children usually do not interact regularly with them at home. When parents try to reach out to their child, they often result to conflicts because their child would not engage with them. Moreover, parents have hard time in communicating to their child that is why they are often not aware of the whereabouts of their child. Thus, parents will resort to asking help from the teachers in their efforts to solve the conflicts at home like the disobedience of their child. Similar scenarios are also observed by teachers in school where in these students seldom communicate with the hearing people. They are often found to interact among themselves. The $\mathrm{D} / \mathrm{HH}$ students seemed to create their own community where they can express their feelings and emotions. It is seldom observed that they mingle with the hearing students. Though it can be understood that this situation occurs because of communication barriers but this should not be taken for granted and left unresolved. Efforts should be done to at least mainstream these students in the society which should start at home and in school since interaction with other people helps develop the personality of every individual. Thus, the efforts of bridging the gap between these students and the hearing society should be coming from the persons without disability. In this connection, this research aimed to assess the level of social interaction of deaf and hard of hearing students in a school for the deaf in Cebu City, Philippines in order to provide an action plan based on the results and findings of the study. It is the aim of this plan to enhance the level of social interaction of these students to the hearing people that could help them establish a better relationship with the other members of their community.

\section{Literature Review}

This study is anchored on the Social Interaction Theory by Max Weber (1900, as cited in Humphrey, 2017) which states that social behavior has two components which are the actor and the action or behavior that is attached to the actor. This refers to the interpretation of the individual's behavior towards others to whom he has contact with in which his perceived knowledge with one another that is affected makes this action a social aspect. Since an individual interact with others, interaction involves the person's contact with the environment he or she belongs. Such interactions help the person develop relationship with others which would affect the way they perceive with the 
environment. In other words, a person tends to interact with the people where he feels to belong. In the case of the $\mathrm{D} / \mathrm{HH}$ students, it is difficult for them to interact with the hearing world because of communication barriers which would result to avoidance of communication with the hearing people. These students cannot freely express themselves when they engage with the hearing people. On the other hand, hearing people have struggles interpreting the message conveyed by the deaf (Neese, 2016). One important aspect in interaction is the comfortable engagement of the individuals involved in the interaction because if one finds it difficult to interact it is hard for the person to sustain the interaction. That is why deaf people usually interact only among themselves. They can find comfort with the interactions among themselves however they struggle when they are in the hearing world. Deaf people can communicate effectively through sign language in which the hearing world is not usually familiar with. Thus, this is one of the issues that hinder the social interaction of the deaf and the hearing people.

Mead (1920, as cited in Crossman, 2018) also coined the Symbolic Interaction Theory which explores the social interaction in the aspect of language utilization. He stated that individuals interpret meanings using symbols, but they emphasize that language does not have inherent meaning. Thus, individuals interpret actions of other individuals as means to read what message these individuals would try to convey to others. With the nature of how people put meaning to the actions of others, subjective interpretations of these meanings cannot be avoided because the meanings are relevant to the person who assesses the meaning of things, objects, events or behavior of other people. Consequently, the kind of reaction that a person has will depend on how he interprets the meaning of the events around him. Every person behaves based on what they believe but not on what is objectively true. The way people react to situations during interactions form the bond between the individuals involved if positive reactions are expressed by individuals. On the contrary, uncomfortable situations among individuals hinder them from establishing relationships among themselves. $\mathrm{D} / \mathrm{HH}$ students who have less social interaction at home are the results of their feelings of being neglected or given less attention. They feel that they are less important that is why they create their own world. Once their world is disturbed by the family members, they react defensively in order to maintain what they in their own circle (Muscato, 2018). The hearing people tend to treat the deaf as burden in their part when these people are involved in the interactions. It is hard for the hearing people to interpret the meaning of the actions of the deaf. In the same way that the deaf people try to pretend to understand the messages delivered to them in order to show that they can understand like normal people (BenNoun, 2015). In situations like these, conflicts may arise because this could result to misunderstanding among the people communicating. Further, the deaf are often victims of stereotype because their disability is not seen evident on their physical appearance. Knowing a person is deaf will make a normal person avoid engagement because he finds it difficult to deal with deaf people (Crossman, 2018). 
Since the deaf and hard of hearing students have difficulties in interacting with the hearing people, they are often put in places where they find comfortable. Just like in schools, when these students are mainstreamed in regular classes, they have hard time catching up with the lessons. Though these students are mainstreamed in regular classes in some schools, there are also schools which cater deaf and hard of hearing students only. It is mandated in the Philippine R. A. 7277 also known as the "Magna Carta for Disabled Persons" which stipulates that the "State shall establish, maintain and support complete, adequate and integrated system of special education for hearing impaired and other types of types of disabilities". Here, the Department of Education is entrusted to implement the law on the students with special needs. The aim of this law is to provide students with special needs equal access to high quality education through the creation of special education centers. In these schools, the needs of the students are addressed by teachers who are trained on teaching students with special needs. The deaf students are one of the beneficiaries of this law. They receive instruction that fits their capability and skills at the same time assessment are modified so that their skills and knowledge are assessed effectively.

However, in special schools, there is limited interaction of the deaf and hard of hearing students towards their environment. The social development of students who are enrolled in special classes are affected since there will be less contact with the hearing people. Only the teachers who can hear can interact with these students. In the society, these students most of the time encounter hearing people. With the kind of environment these students are in, they can only usually communicate among themselves. Thus, social relationships are only formed among these students (Schick et al, 2012). School works are usually done by themselves with less contribution from the hearing people. When $\mathrm{D} / \mathrm{HH}$ students have difficulties performing school-related tasks, they can only ask assistance from their peers or from their teachers. The assistance that they receive is limited among them only.

At home, these students seldom receive support from the family members. They are often left alone with their schoolwork. Having this kind of situation will have negative effects on the $\mathrm{D} / \mathrm{HH}$ students' performance in school. It is important that students receive enough support in school and at home because not all the time students are able to accomplish school tasks alone. There are times that students need assistance in performing school-related tasks (Sahagun, 2015).

In the study of LaBelle et al. (2013) on the social communication of the deaf people and the hearing people, they predicted that the hearing people have negative perceptions on the deaf people that will cause them anxiety if the deaf people are present in the group. This anxiety refers to the feeling of the hearing people of having discomfort in communication with the deaf people because they have the negative perceptions that they cannot communicate effectively with the presence of the deaf people in a certain group. However, an increased contact of the hearing people with the deaf would lessen the anxiety that the hearing people would feel if the deaf are present in the group. 
Furthermore, the hearing people have the feeling of social dominance over the deaf which would lead to their negative attitudes towards them.

Batten, Oakes and Alexander (2013) stressed that one important aspect of child's development is their social interaction skills. Social skills help protect the child from experiencing different life stressors and personal challenges like those experienced by deaf children in the same way that these skills help in establishing positive peer relationships. Positive peer relationship will help in increasing the child's self confidence, successful adjustments to school transitions and develop positive school attitudes. However, rejection from peers will bring negative effects to the child. If the child experiences isolation, this can cause internal problems like anxiety, depression and low self - confidence which would result to dislike schooling and poor academic performance. Peer relationships help the child practice the skills related to interpersonal interactions like helping others, sharing, and negotiating.

Torres, Saldaña and Rodriguez-Ortiz (2016) conducted a study which compares the processing of social information processing (SIP) skills in deaf and hearing adolescents. They found that deaf adolescents had lower SIP skills compared to the hearing adolescents. However, the deaf female participants had higher SIP skills than the deaf male participants. This implies that in conversation among groups the hearing people can process information faster than the deaf people affecting the social engagement when there is an intergroup communication. On this note, hearing people should be more patient in communicating with the deaf so that they can communicate effectively.

Liu (2013) explored the factors that may influence the academic and social adjustment of deaf students in Taiwan. It was found out that family relationship had a significant association with the students' academic performance. They found that deaf students with less stress related to family had lesser academic difficulties. Otherwise, they will experience social difficulties. However, none of the academic and social adjustment can predict success of the students in college.

Yabbi (2013) investigated the influence of social, economic, and cultural factors to the academic performance of the learners of a certain school in Eastern Africa. Results revealed that social factors had a high extent of influence on the learners' academic performance. Low economic status of learners led to poor performance of the learners in school. Moreover, the negative perception of the community towards deaf people leads to discrimination, low performance in school, poor motivation and segregation in the community where the deaf learners belong.

This review of related literature and studies are the basis for the development of the concept and how the variables interact with each other which are explored in the study. The theories serve as the underlying principles on how the variables examined could possibly be related to each other while the legal basis provides the reasons for the conduct of this undertaking. Results of this study were the basis for an intervention that aims to help the deaf and hard of hearing students. 


\section{Material and Methods}

This study used descriptive-correlational research design. A descriptive-correlational research aims to assess two or more variables and the association that lies between these variables without changing or manipulating the inherent characteristics of the variables (Bhandari, 2021). In this study, the social interaction and academic performance of the $\mathrm{D} / \mathrm{HH}$ students were assessed and a hypothesis testing was conducted to determine whether a significant relationship between these variables exists. A take-all sample was used to determine the respondents due to the small population of the students. The respondents were the junior and senior high school students of a school for the deaf in Cebu City, Philippines. Before the respondents were asked to participate, an informed consent and assent was secured from them. The special education teachers who handled their classes facilitate the process.

The respondents have their classes in self-contained classrooms. Though they are attending classes in this classroom setting, they still have chances to interact with the regular students because the school is within the vicinity of a public national high school. There are also times that teachers invite regular students to observe classes for these students. Thus, there are chances that these students could build friendships among them.

A survey questionnaire was used to gather the data needed in this study which has two parts. Part 1 contains statements that assessed the profile of the respondents in terms of their age, gender, degree of hearing loss, and number of siblings. Part 2 is a researcher-made questionnaire with 40 statements divided into four components such as the interaction of the $\mathrm{D} / \mathrm{HH}$ students with their family members, teachers, hearing students and their peers. The statements were rated by the respondents as to the extent of their interaction with the people around them using a 5-point Likert scale namely: 5Strongly Agree, 4-Agree, 3-Neutral, 2-Disagree, and 1-Strongly Disagree. The instrument was developed through the literature readings and guidance of an expert in special education. To check its validity, a special education expert, a statistician and a college of special education professor were consulted. Moreover, its reliability was tested using Cronbach's alpha observing the greater than 0.07 threshold to ensure a high internal consistency of the statements measuring the construct. The instrument was pilot tested to 13 deaf and hard of hearing students at a public state university which yielded a Cronbach's alpha of 0.886 showing that a high internal consistency was achieved. Further, the academic performances of the respondents were determined using the average of their First to Third Quarter grades with help of their respective adviser. 


\section{Results and Discussion}

This section presents the results of the data gathered from the 49 respondents in terms of their profile, social interaction, and academic performance. The test on the relationship of the respondents' interaction and academic performance is also presented.

Table 1: Profile of the respondents

\begin{tabular}{|l|c|c|}
\hline Profile & f & \% \\
\hline Gender & 23 & 46.94 \\
\hline Male & 26 & 53.06 \\
\hline Female & $\mathbf{4 9}$ & $\mathbf{1 0 0 . 0 0}$ \\
\hline Total & 4 & 8.16 \\
\hline Age & 12 & 24.49 \\
\hline 25 and above & 31 & 63.27 \\
\hline $21-24$ & 2 & 4.08 \\
\hline $17-20$ & 49 & $\mathbf{1 0 0 . 0 0}$ \\
\hline $13-16$ & 36 & 73.47 \\
\hline Total & 13 & 26.53 \\
\hline Degree of hearing loss & $\mathbf{4 9}$ & $\mathbf{1 0 0 . 0 0}$ \\
\hline Deaf & \multicolumn{2}{|}{} \\
\hline Hard of hearing & 10 & 20.41 \\
\hline Total & 21 & 42.86 \\
\hline Number of siblings & 18 & 36.73 \\
\hline 5 and up & $\mathbf{4 9}$ & $\mathbf{1 0 0 . 0 0}$ \\
\hline $3-4$ &
\end{tabular}

Table 1 presents the profile of the respondents in terms of their gender, age, degree of hearing loss, and the number of their siblings. It can be gleaned in the table that most of the respondents are female students who comprised 53.06 percent of the respondents while most of them are having an age range from $17-20$ years old that is 63.27 percent. The distribution of the ages of the respondents shows that most of them started schooling at a later age or they had stop at certain grade level because their ages were older than the expected age of high school students. Moreover, there were 36 or 73.47 percent of the respondents who were deaf students. Only 13 or 26.53 percent of them were hard of hearing students. The data imply that most of the students cannot hear anything so their only means of communication is through sign language. It would be harder for them to communicate to people who do not know sign language. Some of them were hard of hearing students which means that they can hear a little bit of sounds which can help them in communicating to others. However, the sound that they hear is not reliable as a means of communicating. They still have to use sign language when they communicate. Moreover, Table 1 shows that there were 21 or 42.85 percent of the respondents had 3 to 4 siblings which is followed by 18 or 36.73 percent of them who had 1 to 2 siblings. There 
were 10 or 20.41 percent of them who had 5 siblings and up. Children who are from a family with many children can receive lesser attention from parents with fewer children. Thus, it is important to know the number siblings that the respondents have so that this study can provide a better idea on how much support these respondents could have received from their parents. A family with many children can be advantageous to deaf children because they can possibly interact with any of their siblings but can be disadvantageous to them when the members of the family have poor sign language skills. Aside from that, parents with many children cannot give much attention to the child who is deaf because they have other children to attend to unless parents are supportive to their child with disability.

Table 2 presents the level of social interaction of the respondents towards their family members, teachers, hearing students and their peers.

Table 2: Respondents' Level of Social Interaction

\begin{tabular}{|l|c|c|c|}
\hline Social Interaction & WM & sd & Verbal Description \\
\hline Family Members & 2.76 & 1.375 & Moderate \\
\hline Teachers & 3.68 & 1.119 & High \\
\hline Hearing Students & 1.46 & 0.663 & Very Low \\
\hline Peers & 3.83 & 0.996 & High \\
\hline Overall Weighted Mean & $\mathbf{2 . 9 3}$ & & Moderate \\
\hline Overall Standard Deviation & & $\mathbf{1 . 0 3 8}$ & \\
\hline Legend: 4.21 - 5.00 Very High 3.41 - 4.20 High 2.61 - 3.40 Moderate 1.81 - 2.60 Low 1.00 - 1.80 Very Low \\
\hline
\end{tabular}

The respondents had high level of social interaction with the teachers and their peers with weighted means of 3.68 and 3.83, respectively. Whereas, they had moderate level of social interaction with their family members with a weighted mean of 2.76 but they had very low level of interaction with the hearing students with a weighted mean of 1.46. The data imply that the respondents can only interact freely when they communicate with people who have skills in communicating through sign language. It was found that the respondents had high interaction with their teachers because teachers handling them know the sign language. On the other hand, they also have high level of interaction with their peers because they freely communicate through sign language. As to the family members, they have limited interaction with them. This could be because not all members of the family are well-versed with sign language. Even most parents have difficulties in communicating with their child because they lack sign language skills. Expectedly, the respondents had very low interaction with the hearing students because most hearing students do not have any knowledge about sign language. As observed in the data, one of the main reasons that hinder the respondents to communicate with the other members of the community is the ability to communicate with them. $\mathrm{D} / \mathrm{HH}$ students prefer to interact with their peers than the hearing students even if they can initiate such interaction because they have difficulties in maintaining interactions with hearing students due to their communication barriers (Antia et al., 2012). 
Table 3: The level of academic performance of the respondents which were measured using the average of their grades from First to Third Grading periods

\begin{tabular}{|l|c|c|c|}
\hline Level & Numerical Range & f & \% \\
\hline Outstanding & $90-100$ & 4 & 8.16 \\
\hline Very Satisfactory & $85-89$ & 16 & 32.66 \\
\hline Satisfactory & $80-84$ & 14 & 28.57 \\
\hline Fairly Satisfactory & $75-79$ & 15 & 30.61 \\
\hline Did not meet the Expectations & Below 75 & -- & -- \\
\hline Total & & $\mathbf{4 9}$ & $\mathbf{1 0 0 . 0 0}$ \\
\hline Average & & \multicolumn{2}{|c|}{$\mathbf{8 3 . 0}$} \\
\hline
\end{tabular}

It can be seen in Table 3 that there were 16 or 32.66 percent of the respondents who had very satisfactory performance while followed by 15 or 30.61 percent of them who had fairly satisfactory performance. Fourteen or 28.57 percent of them had satisfactory performance while only 4 or 8.16 percent of them had outstanding performance in school. The respondents are enrolled in a special school exclusive for the $\mathrm{D} / \mathrm{HH}$ students. They receive modified instruction and assessment. Lessons introduced in their classes are different from those of the regular classes. That is why most of them had better performance in school but there are still students who have difficulties in school. There is still a need for them to improve their performance especially those who had fairly satisfactory performance.

Table 4 presents the test of significant relationship between the social interaction and academic performance of the respondents. The relationship of the academic performance to the social interaction was tested using the four variables of social interaction such as the interaction with the family members, teachers, hearing students, and peers.

Table 4: Correlation analysis on social interaction and academic performance of the respondents

\begin{tabular}{|l|c|c|c|c|c|}
\hline Variables & $\begin{array}{c}\text { r- } \\
\text { value }\end{array}$ & $\begin{array}{c}\text { Strength of } \\
\text { Correlation }\end{array}$ & $\begin{array}{c}\mathbf{p}- \\
\text { value }\end{array}$ & Decision & Remarks \\
\hline $\begin{array}{l}\text { Interaction with Family Members } \\
\text { and Academic Performance }\end{array}$ & $0.383^{* *}$ & $\begin{array}{c}\text { Weak } \\
\text { Positive }\end{array}$ & 0.007 & Reject Ho & Significant \\
\hline $\begin{array}{l}\text { Interaction with Teachers and } \\
\text { Academic Performance }\end{array}$ & 0.229 & $\begin{array}{c}\text { Negligible } \\
\text { Positive }\end{array}$ & 0.114 & $\begin{array}{c}\text { Do not } \\
\text { Reject Ho }\end{array}$ & $\begin{array}{c}\text { Not } \\
\text { Significant }\end{array}$ \\
\hline $\begin{array}{l}\text { Interaction with Hearing Students } \\
\text { and Academic Performance }\end{array}$ & $0.327^{*}$ & $\begin{array}{c}\text { Weak } \\
\text { Positive }\end{array}$ & 0.022 & Reject Ho & Significant \\
\hline $\begin{array}{l}\text { Interaction with Peers and } \\
\text { Academic Performance }\end{array}$ & -0.011 & $\begin{array}{c}\text { Negligible } \\
\text { Negative }\end{array}$ & 0.942 & $\begin{array}{c}\text { Do not } \\
\text { Reject Ho }\end{array}$ & $\begin{array}{c}\text { Not } \\
\text { Significant }\end{array}$ \\
\hline **significant at $\mathrm{p}<0.01\left(\right.$ two - tailed); ${ }^{*}$ significant at p<0.05 (two-tailed) \\
\hline
\end{tabular}

The computed value of Pearson $r$ which is 0.383 indicates that there is a weak positive correlation between interaction of the respondents with the family members and their academic performance. The $p$-value of 0.007 is lesser than the $0.01(p<0.01)$ significance 
level indicates a significant relationship between the interaction of the respondents with the family members and their academic performance. The family of D/HH students is one of the support structures that they can rely on with their school-related tasks. However, a family with many children can also be a cause of competition among the children who wants attention from their parents. The $\mathrm{D} / \mathrm{HH}$ children will be put to disadvantage among members without disabilities. Moreover, parents cannot monitor the whereabouts of all their children which leads to their child's independence but with lesser academic achievement for children who are attending school (Rezaei-Dehaghani, Keshvari, \& Paki, 2018). The finding of this study is supported by the findings of Liu (2013) which found that family relationship had a significant association with the students' academic performance. Moreover, Yabbi (2013) revealed that social factors had a high extent of influence on the learners' academic performance.

Moreover, the computed value of Pearson $r$ which is 0.229 means that there is a negligible positive correlation between the interaction of the respondents with their teachers and their academic performance. The p-value of 0.114 which is greater than the 0.05 ( $p>0.05$ ) level of significance indicates that there is no significant relationship between the interaction of the respondents with their teachers and their academic performance. The social interaction of the $\mathrm{D} / \mathrm{HH}$ students with their teachers does not affect their performance. It is more interesting when teachers are able to help improve students' performance by their interaction with the students. Teachers are in the best position to help the students with hearing impairment in their classroom by empowering them with knowledge on how to understand information they receive. This can be done by assessing the students' capabilities to process information and measuring their comprehension level (Victory, 2020).

As to the computed value of Pearson $r$ for the interaction of the respondents with hearing students which is 0.327 denotes that there is a weak positive correlation between their interaction and their academic performance. The p-value of 0.022 which is lesser than the $0.05(p<0.05)$ significance level suggests that there is a significant relationship between the interaction of the respondents with the hearing students and their academic performance. It can be considered that the interaction of $\mathrm{D} / \mathrm{HH}$ students with hearing students is beneficial to their performance in school. The regular visit of the hearing students to the school for the deaf has a positive effect to their performance since they can build friendships among themselves through their interactions during this visit.

Lastly, the computed value of Pearson $r$ which is -0.011 indicates that there is a negligible negative correlation between the respondents' interaction with their peers and their academic performance. The $p$-value of 0.942 which is greater than the $0.05(p>0.05)$ significance level means that there is no significant relationship between the respondents' interaction with their peers and their academic performance. The social interaction of the $\mathrm{D} / \mathrm{HH}$ students among their peers does not affect their performance in school. It is when they communicate among themselves where they have the freedom to maintain the 
interactions among themselves because they feel comfortable. Hence, they can explore beyond school related-topics and find enjoyment in their social interactions.

\section{Conclusion}

The study aimed to assess the social interaction of the $\mathrm{D} / \mathrm{HH}$ students with the other members of their community. Given the results, it can be concluded that the $\mathrm{D} / \mathrm{HH}$ students had high social interaction with people who knows sign language like their teachers and their peers however their interaction with these people do not affect their academic performance. On the other hand, their interaction with their family and the hearing students can positively affect their academic performance. The family of the $\mathrm{D} / \mathrm{HH}$ students plays a significant role in improving their performance in school. Thus, enhancing the interaction among the family members with the $\mathrm{D} / \mathrm{HH}$ students would be beneficial on their scholastic performance because the $\mathrm{D} / \mathrm{HH}$ can freely share their emotions, feelings, and problems on school-related matters to any member of the family when members of the family are proficient in communicating with the $\mathrm{D} / \mathrm{HH}$ so they can assist them in their schoolwork and assignments. Interestingly, the hearing students can reinforce the $\mathrm{D} / \mathrm{HH}$ students in their schoolwork and assignments when they are able to communicate well with the $\mathrm{D} / \mathrm{HH}$ students. Hence, increasing their interaction with these students can possibly help in improving the $\mathrm{D} / \mathrm{HH}$ students' academic performance in school.

\section{Conflict of Interest Statement}

The authors declare no conflicts of interests.

\section{About the Authors}

Janine Joy L. Tenerife (Dev.Ed.D.-SpEd) holds a bachelor's degree in Elementary Education major in Special Education. She also obtained her master's in education major in Special Education and her doctorate degree in Development Education major in Special Education from Cebu Technological University-Main Campus. She is an Instructor of Cebu Technological University-Main Campus. She teaches undergraduate, master's, and doctorate students who major in Special Education. She has mentored undergraduate and postgraduate students in research writing which specialized in Special Education. She has presented research in International Conferences on Special Education. She joined training and workshops related to special education like IEP Preparation and Process for Special Education, Formative Assessment for Preschool and SpEd, Transition Curriculum in SpEd, SpEd Identification and Intervention in the Inclusive setting, and other relevant SpEd topics. She has co-authored research publications in different fields of education such as special education and social sciences. Emerson D. Peteros (Dev.Ed.D.) holds a bachelor's degree in Secondary Education major in Mathematics. He also obtained his Master in Education major in Teaching Mathematics 
and his doctorate degree in Development Education from Cebu Technological University Main Campus, Cebu City, Philippines. At present, he is an Instructor of Cebu Technological University Main Campus where he teaches math related subjects. Moreover, he teaches Statistics and Research for the post graduate studies in the same university. He has mentored undergraduate and post graduate students in research writing. He has co-authored research publication in different fields of education such as mathematics, early childhood and special education.

Susana D. Manreal (MA.Ed.) earned her degree on Master of Arts in Education major in Special Education from Cebu Technological University Main Campus, Cebu City, Philippines. She is a special education teacher in First High School for the Hearing Impaired, Cebu City, Philippines. She is an advocate on the awareness of the needs of the deaf and hard of hearing people in the society.

Lilibeth C. Pinili (Dev.Ed.D.SpEd) holds a bachelor's degree in Elementary Education major in Home Economics Livelihood Education and minor in Filipino. She also obtained Master in Education major in Special Education and had earned units in Master of Arts in Vocational Education. She also obtained her doctorate degree in Development Education major in Special Education at Cebu Technological University Main Campus where she teaches special education related subjects. Moreover, she is a chairman for online program in Graduate teacher Education in the same university. She has coauthored research publications in different fields of education such as special education, mathematics, guidance and counselling.

John V. De Vera (Dev.Ed.D.) holds a bachelor's degree in Computer Science from University of San Jose-Recoletos, Cebu City, Philippines. He obtained a certificate in professional education from Cebu Normal University, Cebu City, Philippines and is a licensed professional teacher. He also obtained his Master in Education major in Teaching Mathematics and his doctorate degree in Development Education from Cebu Technological University Main Campus, Cebu City, Philippines. He is an Instructor at Cebu Technological University Naga Extension Campus where he teaches mathematics subjects. Furthermore, he teaches Statistics and Professional Education subjects for undergraduate and postgraduate studies in the same university. He has co-authored research publications in different fields of education such as mathematics, early childhood and special education.

Jesilyn D. Peconcillo (M.Ed.) is a Teacher III in the Department of Education - Talisay City Division, Cebu, Philippines. She holds a bachelor degree in Elementary Education in Early Childhood Education. She also obtained her Master's degree major in Early Childhood Education from Cebu Technological University Main Campus, Cebu City, Philippines. She is currently teaching in Vicenta A. Manreal Elementary School where she is handling Kindergarten learners.

Lindley S. Saladaga (MAT-SpEd) earned his Master of Arts in Teaching Special Education major in Hearing Impairment from Southwestern University, Cebu City, Philippines. He is an instructor for the deaf at Cebu technological University Main 
Campus, Cebu City, Philippines. He also teaches about deaf culture, deaf awareness, and sign language to the post graduate students in the same university. He is a member of World Association of Sign Language Interpreters (WASLI). He has travelled in different countries to attend trainings and conferences for the deaf. He is an advocate in empowering the deaf people in the community by assisting them for employment and teaching them financial education.

\section{References}

Antia, S. D., Kreimeyer, K. H., Metz, K. K., \&Spolsky, S. (2012). Peer Interactions of Deaf and Hard-of-Hearing Children. The Oxford Handbook of Deaf Studies, Language, and Education, Volume 1, Second Edition (2ed.) DOI:10.1093/oxfordhb/9780199750986.013.0013

Batten, G., Oakes, P. M. \& Alexander, T. (2013). Factors Associated with Social Interactions Between Deaf Children and Their Hearing Peers: A Systematic Literature Review. The Oxford Handbook of Deaf Studies, Language, and Education, Volume 1, Second Edition (2 ed.).

Ben-Noun, L. (2015). Communication skills in the disabled. https://www.researchgate.net/publication/281784542 COMMUNICATION SKIL LS IN THE DISABLED

Bhandari, P. (2021). An introduction to correlational research. https://www.scribbr.com/methodology/correlational-research/

Correll, R. (2017). What Challenges Still Exist for the Deaf Community?.https://www.verywellhealth.com/what-challenges-still-exist-forthe-deaf-community-4153447

Crossman, A. (2018). What is Symbolic Interactionism?. https://www.thoughtco.com/symbolic-interaction-theory-3026633

Hankins, R. C. (2015). Social interaction between deaf and hearing people. https://core.ac.uk/download/pdf/148695046.pdf

Humphrey, H. (2017). Social Interaction Theories. https://classroom.synonym.com/social-interaction-theories-12080765.html

LaBelle, S., Booth-Butterfield, M., \& Rittenour, C. E. (2013). Attitudes toward profoundly hearing impaired and deaf individuals: Links with intergroup anxiety, social dominance orientation, and contact. Western Journal of Communication, 77(4), 489-506. doi:10.1080/10570314.2013.779017

Liu, C. (2013). Academic and social adjustment among Deaf and hard of hearing college students

Taiwan.https://kuscholarworks.ku.edu/bitstream/handle/1808/15054/liu ku 0099 $\underline{\text { d } 13143 \text { data 1.pdf? sequence }=1}$ 
Muscato, C. (2018). Social Interaction Theory, Social Roles \& the Presentation of Self. https://study.com/academy/lesson/social-interaction-theory-social-roles-thepresentation-ofself.html

Neese, B. (2016). Intercultural Communication: High- and Low-Context Cultures. https://online.seu.edu/high-and-low-context-cultures/

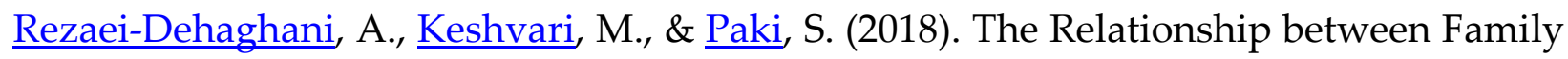
Functioning and Academic Achievement in Female High School Students of Isfahan, Iran, in 2013-2014. Iran I Nurs Midwifery Res. 23(3): 183187.doi: $\underline{10.4103 / i j n m r . I J N M R ~} 8717$

Sahagun, L. (2015). Building Parent-Teacher Relationships to Boost Student Reading Ability. https://www.readinghorizons.com/blog-roll/the-importance-of-buildingparent-teacher-relationships

Schick, B. et al. (2012). School Placement and Perceived Quality of Life in Youth Who Are Deaf or Hard of Hearing. Journal of Deaf Studies and Deaf Education. 18(1), 47 61.

Spears, L. R. (2012). Social Presence, Social Interaction, Collaborative Learning, and Satisfaction in Online and Face-to-Face Courses. https://lib.dr.iastate.edu/cgi/viewcontent.cgi?article=3983\&context=etd

Torres, J., Saldaña, D. \& Rodriguez-Ortiz, I. (2016). Social Information Processing in Deaf Adolescents. Journal of Deaf Studies and Deaf Education, 2016, 326-338.

Victory, J. (2020). How hearing loss affects school performance. https://www.healthyhearing.com/report/52433-How-hearing-loss-affects-schoolperformance

Wanjiru, T. N. (2014). Parental attitudes towards children with hearing impairment and academic performance: A case of Kambui school for the deaf, Githunguri

District, Kiambu County, Kenya.https://irlibrary.ku.ac.ke/bitstream/handle/123456789/11964/Parental\%20A ttitudes $\% 20$ towards $\% 20$ Children $\% 20$ with\%20Hearing $\% 20$ Impairment $\% 20$ and $\% 2$ 0Academic $\% 20$ Performance.pdf?sequence $=1 \&$ is Allowed $=y$

Yabbi, Opiyo P. Judith (2013). Influence of Socio - Economic and Cultural Factors on Academic Performance of Hearing-Impaired Pupils at St. Martin Primary School, Kakamega County, Kenya. Masters thesis, Catholic University of Eastern Africa. 
Janine Joy L. Tenerife, Emerson D. Peteros, Susana D. Manreal,

Lilibeth C. Pinili, John V. de Vera, Jesilyn D. Peconcillo, Lindley S. Saladaga

SOCIAL INTERACTION AND ACADEMIC PERFORMANCE OF DEAF

AND HARD OF HEARING STUDENTS IN CEBU CITY, PHILIPPINES

Creative Commons licensing terms

Authors will retain the copyright of their published articles agreeing that a Creative Commons Attribution 4.0 International License (CC BY 4.0) terms will be applied to their work. Under the terms of this license, no permission is required from the author(s) or publisher for members of the community to copy, distribute, transmit or adapt the article content, providing a proper, prominent and unambiguous attribution to the authors in a manner that makes clear that the materials are being reused under permission of a Creative Commons License. Views, opinions and conclusions expressed in this research article are views, opinions and conclusions of the author(s). Open Access Publishing Group and European Journal of Special Education Research shall not be responsible or answerable for any loss, damage or liability caused in relation to/arising out of conflict of interests, copyright violations and inappropriate or inaccurate use of any kind content related or integrated on the research work. All the published works are meeting the Open Access Publishing requirements and can be freely accessed, shared, modified, distributed and used in educational, commercial and non-commercial purposes under a Creative Commons Attribution 4.0 International License (CC BY 4.0). 